\title{
Family Relations of Stock Characters in Atellan Farce - a Few Remarks on the Influence of Palliata on Atellana
}

Joanna Pieczonka

(University of Wrocław)

\begin{abstract}
The article presents possible relationships between two types of Roman comedy: palliata and Atellana; it focuses especially on the influence of palliata on the literary Atellan farce in the field of stock characters. The subject of this paper are family figures, i.e. uxor, senex, adulescens, virgo, servi. There are two kinds of evidence for these personae dramatis having been borrowed into Atellana - the plays, titles and fragments. All of these aspects are analysed in conjunction with relevant passages from palliata. It appears that Atellana employs all of the family masks with their specific features but at the same time often transforms them, exaggerating their sexual actions and using more terms of abuse in their depiction. The author gives English translations for the quoted Atellana fragments.
\end{abstract}

\section{Keywords}

palliata; Atellana; Pomponius Bononiensis; Novius; stock characters

Atellana was staged in Italy for over eight centuries. Perhaps the first impromptu performances of this kind began in the $4^{\text {th }}$ century BC in Atella (Liv. 12, 12, 2; Cic. Fam. 7, 1, 3; Tac. Ann. 4, 14) and the last performances occurred possibly in the $4^{\text {th }}$ century AD (Arnobius, Adversus nationes 7, 33; st. Jerome, Epistula 52, 2). In the meantime other types of comedies were presented on Roman stages; e.g. fabula palliata was first performed in the year of $240 \mathrm{BC}$. Therefore, palliata is much younger than Atellana, but Atellana also existed after palliata's decline and it developed into literary form in the $1^{\text {st }}$ century BC. What is interesting is that we may notice mutual influences between these two types of comedy ${ }^{1}$ - Gesine Manuwald ${ }^{2}$ calls these relations a cross-fertilization, but the influences of one comedy on the other proceed in different directions in two periods: at first the pre-literary Atellana has an impact on palliata, and later palliata affects the literary

1 Lefèvre (2010: pp. 15-36).

2 Manuwald (2011: p. 172). 
Atellana. In my article I wish to examine the second-mentioned relation, and the scope of my interest will concern especially family matters which were the main theme of the plot in the palliata comedy. The challenge will be to check whether the family characters from palliata appear in the popular Atellan farce.

Palliata had a catalogue of stock characters ${ }^{3}$ appearing in the plays; among them we may distinguish two groups of masks: ${ }^{4}$ the family characters and the professional ones. In this article I wish to focus only on these dramatis personae which play family roles: ${ }^{5}$ senex - this is an old man, appearing in the comedy as a husband and a father; matrona an old woman as a wife and a mother; adulescens - a young man as a son; virgo - a young woman as a daughter; and slaves, servi, who also belonged to the family. The Atellan farce presented four stock characters ${ }^{6}$ (Bucco - a stupid, loquacious braggart; Maccus a stupid glutton and a clown; Pappus - a stupid, naive old man; and Dossennus - a clever crafty crook), but I wish to show that it also employed to some extent the mentioned dramatis personae from palliata. There are two types of proof for this phenomenon: the titles and the preserved fragments of Atellana (which I quote in this article according to the edition of Frassinetti 1967), created mainly by two authors: Lucius Pomponius Bononiensis and Quintus Novius. Titles concerning family characters and family matters are as follows:

1. titles ${ }^{7}$ of the plays by Pomponius: Adelphi ("Brothers"), ${ }^{8}$ Dotalis ("Belonging to a Dowry"), Dotata ("Dowered Wife"), Macci Gemini ("Maccuses the Twins"), Macci Gemini Priores ("Maccuses the Younger Twins"), Maccus Virgo ("Maccus the Virgin"), Synephebi ("Fellow Adolescents"), Sponsa pappi ("Fiancée of pappus"), Nuptiae ("Engagement") these are 9 of the 71 titles by Pomponius;

2. titles of the plays by Novius: Dotata ("Dowered Wife"), Duo Dossenni ("Two Dossenuses"), Gemini ("The Twins"), Virgo praegnans ("Pregnant girl") - these are 4 of the 44 titles by Novius.

The titles quoted above, which refer to such family members as brothers and twins, in my opinion are too vague to say anything substantial about the stock characters they could describe. Nevertheless, I decided to mention them, to include in my paper the whole scope of family matters and to show that the popular farce used the conventional

3 The catalogue of these personae dramatis appears not only in Plautine and Terentian comedies, but also in the plays by Livius Andronicus and Naevius. See Wright (1974: pp. 16-19; 35-38; 47-50; 53-54).

4 Such a distribution of stock characters is presented e.g. by Duckworth (1952: pp. 236-271) and Skwara (2001: pp. 33-34; 86-89). For more detailed distribution see Della Corte (1978: pp. 155-194). See also Hurbánková (2014: pp. 8-13).

5 The characters known as professional types, probably taken from palliata and mentioned in Atellana were: leno - the pimp (Pomp. Leno), miles - the soldier (Pomp. Maccus Miles), parasitus - the parasite (Pomp. Prostibulum frg. III Frassinetti: ego quaero quod comedim; has quaerunt quod cacent: contrariumst), medicus - the doctor (Pomp. Medicus), meretrix - the prostitute (Nov. Hetaera).

$6 \quad$ Cf. e.g. Sitti (1895: pp. 27-30); Graziani (1896: pp. 388-392); Pezone (1969: pp. 206-210); Hurbánková (2008: pp. 75-77; 2009: pp. 7-11).

7 For typology of the titles of Atellana see Debouy (2010: pp. 157-168).

8 The titles and fragments of Atellana and of Caecilius Statius' plays are translated by the author of the article. Fragments of Caecilius Statius are quoted according to Ribbeck (1898). 
motifs from palliata, especially a double motif. ${ }^{9}$ A number of the mentioned titles ${ }^{10}$ confirm this borrowing: Adelphi, Macci Gemini, Macci Gemini Priores, Gemini, Duo Dossenni. Unfortunately, none of the preserved fragments allows us to observe the implementation of this motif in a play. We cannot be sure if the play Adelphi had any features similar

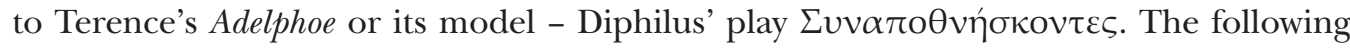
fragment from the comedy Gemini ("Twins") only alludes to the theme of a family, but it does not say anything about the brothers:

Nov. Gemini (v. 40): o domus, parata pulchrae familiae, festiviter!

„O home, prepared for the benefit of this wonderful family for the feast!"

Nonetheless, we may assume that the popular farce probably used a double motif or entwined with it a qui pro quo motif, both known from palliata, just to make a parody of this conventional element of a plot. Parody was created e.g. by letting the stock characters from Atellana to play the part of twins (Macci Gemini, Macci Gemini Priores, Duo Dossenni). Because of the scarce fragments we cannot be sure if the whole plot of palliata could have been copied and transformed, or the whole world presented in the play could have been imitated or parodied. However we can be sure that Atellana used family characters from palliata, as I will prove below.

\section{Matrona - Uxor}

As we can see in the short catalogue of titles above, there are two plays by Pomponius and Novius entitled Dotata ("Dowered wife") and one that is called Dotalis ("Belonging to a dowry"). All of them refer to the palliata's mask of uxor, a wife. The wife is often considered in the palliata comedy as a negative character, as she is the source of her husband's misery, ${ }^{11}$ she rules him, ${ }^{12}$ thanks to a dowry which she brought marrying the man (she is called uxor saeva). Passages from the comedies by Caecilius Statius and Plautus show this image of a wife.

Caec. St. Plocium frg. I R $\mathrm{R}^{3}$ : Is demum miser est, qui aerumnam suam nescit occultare

foris: ita me uxor forma et factis facit, si taceam, tamen indicium.

Quae nisi dotem, omnia, quae nolis, habet: (...)

"The most unhappy is the one who cannot hide his misery before the world. This is the way

9 The motif is exploited e.g. in Plautus' Amphitruo, Bacchides, Menaechmi, Miles gloriosus; see also Maurice (2003: pp. 164-193).

10 See Hurbánková (2010: pp. 72-73).

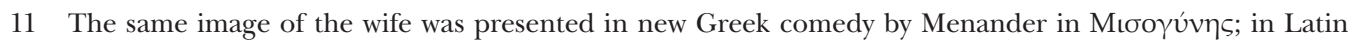
comedy probably by Naevius (the wife is called here morigera: Tarentilla frg. XI $\mathrm{R}^{3}$ ), by Caecilius Statius in comedy Plocium (frg. I, II, III R ${ }^{3}$ ), by Terence in plays Heautontimorumenos and Phormio. Odium mulierum was a main theme in the play by Atilius, entitled Misogynos (Wright 1974: pp. 70-71).

12 Caecilius Statius uses an expression liber servio to show the position of a husband with respect to his wife (Plocium frg. I, $4 \mathrm{R}^{3}$ ). The same thought was expressed by Titinius (Prilia frg. 1 Guardí): verum enim dotibus deleniti ultro etiam uxoribus ancillantur. Cf. also Afran. Emanc. frg. 21 Daviault; Pl. As. 898; Cas. 409; Men. 766-767; Mos. 280-281; Ter. An. 950-951; Ph. 693. 
how my wife torments me by her looks and deeds. If I said nothing, even then she would prove it. The only thing you could wish from her, was a dowry (...)"

Pl. As. 87:

DE. argentum accepi, dote imperium vendidi ${ }^{13}$

"Sold myself! Gave up my authority for a dowry!" 14

Uxor dotata ("a dowered wife"), ${ }^{15}$ a character from palliata and originating earlier from

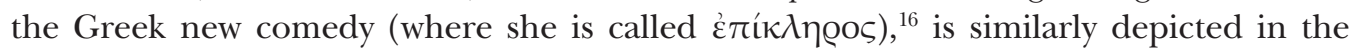
Atellan farce. In a fragment of Atellana by Pomponius we can see a picture of a wife having not only physically, but also mentally repulsive features. The passage shows that a dowered woman (she is called dotata) is advanced in years, hideous and crafty - her characteristics are emphasized in the text by alliterations.

Pomp. Pannuceati frg. I (vv. 83-85): sed meus

frater maior, postquam vidit me vi deiectum domo,

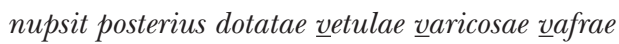

"But my older brother, when he saw me thrown out of the house by force, married quite soon a wife dowered, aging, having varicose veins and cunning."

In my opinion the title of this comedy - Pannuceati ("Dressed in rags") might denote both brothers, but one of them, the elder, because of the poverty, marries the described uxor dotata. Frassinetti ${ }^{17}$ writes that the title concerns only the younger brother, thrown out of the family house.

As we may see in the quoted passages, a wife is often hated by her husband and the main reasons for this hatred are: her age - she is always presented as old, her ugliness and a bossy character, connected with her power, given by the dowry. Therefore, a husband wishes her death ${ }^{18}$ or, if possible, he wants to divorce her. ${ }^{19}$ In the fragment from Caecilius Statius' play entitled Plocium ("The Necklace") we read such a thought expressed by the husband:

Caec. St. Plocium frg. III R $\mathbf{R}^{3}$ : Placere occepit graviter, post quam emortuast.

"I really began liking my wife, when she had died."

13 Text of the Plautine comedies according to Lindsay (1910).

14 Translations of Plautus' comedies by Nixon (1916-1924); translation of Terence's comedies by Barsby (2001).

15 About dowered wives see Schuhmann (1977: pp. 45-65); Lelewska (1998: pp. 15-23).

16 Cf. the title of the play by Diodorus 'E $\pi$ ík $\lambda$ ¡os and the same title by Caecilius Statius Epikleros - "Heiress".

17 Frassinetti (1967: pp. 104-105); Hurbánková (2010: p. 71).

18 Cf. Pl. Cas. 227: sed uxor me excruciat, quia vivit; As. 21-22, 901; Trin. 55-56, 58. Megadorus from Plautine Aulularia prefers to die first and then marry a dowered wife - Pl. Aul. 154: ut quidem emoriar priu' quam ducam.

19 The men from Plautus' Trinummus want to exchange their wives to get rid of them (Pl. Trin. 59: ME. vin commutemus, tuam ego ducam et tu meam?). 
In the fragment from Pomponius' comedy Citharista ("A lyre player”) an analogical farcical idea is given.

Pomp. Citharista (vv. 28-29): noli, quaeso, irascere;

more fit moriri quisque uxorem ut suam velit.

"Please, do not be angry; it is in the tradition that everyone wishes his wife to die."

If a husband ${ }^{20}$ acquires his own money, he does not need his wife's dowry anymore and he can divorce her - as we learn from the fragment of Atellana by Novius.

Nov. Tripertita (vv. 87-88): postquam

se vidit herem, desubito divortium fecerunt.

"When he knew he acquired an inheritance, they instantly got a divorce."

A wife without a dowry, but good-natured and modest is praised by one of the men in the Plautus' comedy Aulularia:

Pl. Aul. 498-500: ME. nulla igitur dicat 'equidem dotem ad te attuli

maiorem multo quam tibi erat pecunia;

enim mihi quidem aequomst purpuram atque aurum dari...'

“Then you wouldn't hear them saying: Well, sir, you never had anything like the money I brought you, and you know it. Fine clothes and jewellery, indeed!”

In this passage Nixon translates purpuram atque aurum as "fine clothes and jewellery", because purple and gold were considered to be luxury products and were often desired by spendthrift wives. ${ }^{21}$ The same opinion is announced by one of the characters in an Atellan farce, written by Novius.

Nov. Tabellaria frg. I (v. 84): qui habet uxorem sine dote, pannum positum in purpura est

"the one who has a wife without a dowry, has a rag steeped in purple"

Nov. Tabellaria frg. II (v. 85): dotem ad nos nullam attulas

"You have not brought a dowry to us"

In the first fragment the speaker says that a wife without a dowry lets her husband enjoy his fortune. As in Plautus - the word purpura refers here to luxurious life, but it is contrasted in the fragment with the noun pannum which means "a rag". These contradictory

20 The character of an avaricious husband and an old man was transferred from Greek new comedy - cf. e.g. Menander's Epitrepontes, "Men at Arbitration".

21 Allusions concerning female love of luxury, when they occur in Plautus' comedies, they often refer to a sumptuary law called lex Oppia. About this law: Culham (1982: pp. 786-793); Kuryłowicz (1994: pp. 43-53); Pieczonka (2007: pp. 114-116). Allusions to lex Oppia and to dowered wives are also present in the Titinius' togata entitled Barbatus. 
words create a comical oxymoron (pannum... in purpura). ${ }^{22}$ This figure of speech seems to emphasize the husband's situation who without a spendthrift wife has even his rags dyed purple. The second passage confirms that a woman did not bring any dowry when marrying her husband. Some scholars claim that the title of this comedy, Tabellaria, refers to this marriage contract, e.g. Frassinetti ${ }^{23}$ translates this title as "La farsa del contratto matrimoniale". It is therefore possible that this Atellana contained a family plot concerning marriage issues.

There are two more fragments of the popular farce where a wife is mentioned, but these passages differ from the above-quoted. These are as follows:

\section{Pomp. Medicus (vv. 78-79): dolasti uxorem. nunc eapropter me cupis}

concidere? etiam rhetorissas?

"You have axed the wife." "And now because of it you want to kill me?" "You even dare to ask?" Pomp. Pappus agricola frg. I (vv. 95-96): nescio quis, molam quasi asinus, urget uxorem tuam, ita opertis oculis simitu manducatur ac molit.

"I do not know who, but he urges / presses your wife, like a donkey presses the mill stone."

"Thus with closed eyes he chews at the same time and grinds mill."

In both fragments the wife is involved in a sexual situation. As Adams ${ }^{24}$ notices, the verb dolare from the first quoted fragment has an obscene sense. Normally it means "to axe, chop into shape, batter", but here it alludes to an intercourse with the wife. The same function in the second sentence has the verb concidere, "to beat, cut", which refers to a sexual contact between two men ${ }^{25}$ performing the dialog preserved in the passage. In the fragment from comedy Pappus agricola the same function have three verbs: urguere $^{26}$ - "to press", manducari ${ }^{27}$ - "to chew" and molere ${ }^{28}$ - "grind in a mill". All of them build a rustic metaphor which has a second sexual meaning - it describes the actions of a male during an intercourse. These two fragments present the character of a wife in a sexual scenery (a woman is compared to the pressed millstone, molam). ${ }^{29}$ This image is unfamiliar to the palliata comedy, where the wife is not presented as a sexual object - in this manner these fragments differ from the earlier mentioned passages modelled on

22 Forcellini's dictionary (1828: p. 82) compares this sentence (having a proverbial character) with a passage from Horace, referring to a concept of decorum and its lack (Ars 1-2): humano capiti cervicem... equinam/ iungere (...).

23 Frassinetti (1967: p. 138).

24 Adams (1990: p. 147); Danese (2010: pp. 111-112).

25 Ibidem.

26 Adams considers urgere as a synonym to comprimere (1990: p. 183).

27 The verb also has an obscene sense according to $O L D$ (s. v. manduco), although neither Adams nor Danese mention this word as having a sexual meaning. Manducari generally means to "chew" or to "eat", therefore in an erotic meaning it should denote, in my opinion, kissing.

28 Adams (1990: pp. 152-153); Danese (2010: p. 113). Cf. Lucil. 278 M.: hunc molere, illam autem ut frumentum vannere lumbis.

29 Although Lindsay emandated molam for asellam - then the donkey would "press" a she-donkey (in a sexual meaning), not a millstone. 
palliata. We may conclude that the character of a wife in Atellana had the features of the uxor $^{30}$ from palliata, but also became an object of erotic jokes - this literary device is very typical of the farcical and obscene nature of Atellana.

\section{Senex - Pater}

The husband, senex, inherited from palliata his feature of an old lusty man - senex amator ${ }^{31}$ who burns with passion for a much younger woman. Such a character appears in many of Plautus' comedies, e.g. in Mercator ("The merchant"), where an old man rivals for the same woman with his son. ${ }^{32}$ Here I wish to give one significant passage from this play.

Pl. Mer. 304-305: (...) DE. amo.

LY. tun capite cano amas, senex nequissime?
„DEM. I L-O-V-E.

LYS. You in love, you, with that hoary head, you poor old good for nothing?"

As the popular farce enjoyed including erotic elements, a lusty old man became an excellent character to employ in the comedy. We can find three fragments of Atellana referring to a senex amator - all of them come from the same comedy entitled Praeco posterior, ${ }^{33}$ which means "The older auctioneer".

Pomp. Praeco posterior frg. I (v. 130): set me exercet senica nequam, neque illo quid faciam scio.

"But he trains me, this depraved old man and I do not know, what to do."

Pomp. Praeco posterior frg. II (vv. 131-132): ad Veneris profectust mane vetulus, votum ut solveret; ibi nunc operatust

"This aging man has gone to the gods of love in the morning to make a sacrifice and now he does it there"

Pomp. Praeco posterior frg. III (v. 133): vis facere ut noverca vetulum derepente deserat?

"Do you wish to make a stepmother to abandon instantly this aging man?"

In the first fragment senex is called nequam, "depraved", as in the quoted Plautus' play nequissimus. The second fragment confirms that this aging man is in love and making sacrifice for the gods of love just to receive their benevolence. In palliata we may find e.g. a senex amator thanking Venus for her kindness in the comedy Casina:

30 In the fragment from Pomponius' Concha (v. 31: vos istic manete: eliminabo extra aedis coniugem) the word coniunx refers possibly to the character of a wife, but we cannot find here any allusion to palliata.

31 About senex amator see Walker (1980).

32 About this motif: Wright (1974: p. 54); Couto (2007: pp. 41-73).

33 There is a one more fragment from this play, spoken by the son of the mentioned senex amator - a young man declares here that he will give his father an earful, when they get outside the house (Pomp. Praeco posterior frg. X, v. 141-143): ego dedita opera te, pater, solum foras/ seduxi, ut nequis esset testis tertius/ praeter nos, tibi cum tunderem labeas lubens. However the fragment does not reveal, if the father could have been a rival for his son and if this was the reason of the son's rebuke. More probable is that the son wanted to warn his father about the danger of divorce (see above frg. III from this comedy). 
Pl. Cas. 841-843: Venu’ multipotens, bona multa mihi

dedisti, huiius quom copiam mi dedisti. OL. O

corpusculum malacum.
"Venus, mighty Venus, what a treasure thou gavest

me when thou gavest me possession of this maiden!

Oh, your tender, tender little body"

The third fragment cited above from Pomponius' Atellan comedy Praeco posterior seems to show the consequences of an old man's (vetulus) romances and passionate love for a younger woman. The wife probably will consider leaving her lusty husband or maybe even divorcing him. Although the suggestion of a woman initiating a divorce was likely a farcical remark, perhaps legally not possible, ${ }^{34}$ we can find an analogical thought in the Plautus' before-mentioned comedy Mercator. Here Dorippa suspects her husband of cheating on her and Dorippa's slave, Syra, announces a comical project of a law, allowing women to initiate a divorce. ${ }^{35}$

Pl. Mer. 817-823:

\section{SY. Ecastor lege dura vivont mulieres}

multoque iniquiore miserae quam viri.

nam si vir scortum duxit clam uxorem suam,

id si rescivit uxor, impunest viro;

uxor virum si clam domo egressa est foras,

viro fit caussa, exigitur matrimonio.

utinam lex esset eadem quae uxori est viro;

\begin{abstract}
"My, my! Women do live under hard conditions, so much more unfair, poor things, than the men's. Why, if a husband has brought home some strumpet, unbeknown to his wife, and she finds it out, the husband goes scot free. But once a wife steps out of the house unbeknown to her husband, he has his grounds and she's divorced. Oh, I wish there was the same rule for the husband as for the wife!"
\end{abstract}

There is one more Atellan farce by Pomponius which also might refer to the character of senex amator - this is the comedy called Sponsa pappi which means "Fiancée of pappus". As I mentioned before, among the stock characters of Atellana was pappus, an old, naive man. The title suggests that this old man may be in love, as he has a woman to marry,

34 Such an opinion we may find in McDonnell (1983: pp. 54-80); Roy (1999: p. 9); Tarwacka (2004: p. 19); Tarwacka (2005: pp. 355-362); an opposite opinion, based on the Plautine passage spoken by Alcmene in Amphitruo (Am. 928: valeas, tibi habeas res tuas, reddas meas), has Rosenmeyer who says that both of the spouses could initiate a divorce already in the times of Plautus (Rosenmeyer 1995: p. 203), also Watson (2005: p. 284). Tarwacka claims that Alcmene announces the divorce formula inversely and the husband will perform the divorce, although provoked by the wife (Tarwacka 2004: p. 11; 2002: pp. 301-308).

35 Leo has seen some analogies between this scene and utterances of women from tragedies of Euripides (Med. 230-247; El. 1036-1040). Leo (1895: pp. 106-109); similarly thinks Enk (1979: pp. 163-164). Tarwacka (2004: pp. 16-18) claims that Plautus has developed this passage by allusions to Roman law, because the Greek sources do not mention divorce. Besides, a woman divorcing her husband would be possible under the Greek law, unlike under the Roman law (Kupiszewski 1962: p. 50). Tarwacka (2004: p. 20) claims that in the Plautine comedy Asinaria there is a joke referring to a wife divorcing her husband (As. 937: DE. male cubandum est: iudicatum me uxor abducit domum). Tarwacka says that the verb abducere alludes to a divorce, as it is an opposition to an expression uxorem domum ducere. 
but it is also possible that the title has a metaphorical sexual meaning. As we may see in a palliata's passage from the comedy Cistellaria, the terms referring to family relations may have erotic meaning.

Pl. Cist. 43-45:

haec quidem ecastor cottidie viro nubit, nupsitque hodie,

nubet mox noctu: numquam ego hanc viduam cubare sivi.
"And so she does, gracious yes, every day to-day,

and again to-night. I've never let her sleep alone, not I."

In the quoted passage the terms regarding family matters create a double entendre joke, ${ }^{36}$ nuber ${ }^{37}$ denotes an intercourse and vidua - a woman not having sexual affairs. Maybe the noun sponsa in the Atellana title Sponsa pappi had the same humorous meaning - if so, it could be understood not as a fiancée, but as a lover of pappus, an old man. This kind of a double entendre joke seems to be employed in another play written by Pomponius - a comedy Prostibulum which means "Prostitute". The word suggesting a wordplay with the verb nubere ("to marry") is an adjective spurcae which describes dirty, filthy women, probably prostitutes.

Pomp. Prostibulum frg. IV (vv. 151-152): quae peditibus nubere

poterant, equites sperant spurcae

"these women who can marry foot-soldiers, they lascivious and filthy, hope to marry horsemen"

Therefore, when we analyse the scarce fragments of Atellan farce or its titles, we can never be sure if nubere means "to marry" or "to sleep with someone", especially that the genre of farce loves wordplays and erotic themes. Such a problem may also concern the title Nuptiae - "Engagement" - it may denote sexual affairs instead of marital ones. Maybe the fragment from an unknown farce of Pomponius referred to a real marriage, not to erotic issues, but the passage is too scarce to confirm this assumption without any doubt.

Inc. fabularum reliquiae frg. II (v. 182): negas

nuptam quaquam

"You claim, that she is certainly not married."

36 Similar wordplay with the word uxor which means "a wife" and "a lover" see in Pl. Cas. 364-365: atqui ego censui aps te posse hoc me impetrare, uxor mea, / Casina ut uxor mihi daretur, et nunc etiam censeo (MacCary \& Willcock 2004: p. 142). Preston presumes (based on: Verg. Ecl. 8, 18; 8, 66; A. 7, 189) that the word coniunx may also be understood as a "spouse" and a "lover", puella amata (Preston 1916: p. 42).

37 Adams (1990: pp. 159-161). 
The figure of senex libidinosus, ${ }^{38}$ an old lusty man, might have appeared in one more Atellana of an unknown author.

Inc. nominis reliquiae frg. IV (v. 4): hircus vetulus capreis naturam ligurit

"An old/aging goat has licked the nature of she-goats"

The adjective vetulus which means "aging" may depict the character of an old man, as we have seen in the earlier quotations (cf. Pomp. Praeco posterior frg. III, v. 133). ${ }^{39}$ Here it describes a goat (hircus), having sexual relations with some female goats. The word natura ${ }^{40}$ from the text may be an euphemism for the sexual parts of either sex. If we look at the passage from the comedy Mercator by Plautus, we will see that this animal metaphor can refer to senex. ${ }^{41}$

Pl. Mer. 274-275:

DE. nec omen illuc mihi nec auspicium placet. quasi hircum metuo ne uxor me castret mea.
"That's no omen, that's no augury I like.

I'm afraid my wife will treat me as if I were the goat!"

All the more, in the same comedy a young woman is called a she-goat (capra; Mer. 229: mercari visus mihi sum formosam capram - "I dreamt that I've bought myself a beautiful she-goat" - says an old man). This might prove that the analysed fragment of Atellana depicts a lusty old man, making love with a young woman. If so, the image of senex would be confirmed here once more.

\section{Adulescens - Filius}

We should notice that the stock character of senex may be confronted in palliata with his wife or he can be presented in the relation with his son, adulescens. Often the comedy focuses on the betrayal between two men, especially the many attempts taken by the son, directly or indirectly, with the help of his slave, to deceive the father and rob him of his money. A young man needs the money to sponsor his love affairs with prostitutes, to throw a party or to pay off his creditor. This motif was known from the Greek new comedy - as we may infer e.g. from the fragment depicting young Nicomachus who has

38 MacCary says that the character of senex libidinosus was unfamiliar to Menander's or Terence's dramas and must have been Plautus' idea (MacCary 1971: pp. 317, note 32; 323). The same: Perna (1955: p. 63).

39 The figure of a father is always presented as being old - such an opinion is confirmed by the fragment from Novius' Agricola (frg. II, v. 2): quid ita? :: quia enim repuerascis, fugitas personas, pater. The son states here that his father wants to be young, which contradicts with the conventional features of his mask (this is a metatheatrical reference).

40 Adams (1990: pp. 59-60). Also Frassinetti (1967: p. 113); Henderson (1975: p. 251); cf. Hopfner (1938: pp. 156, 164).

41 About fabula and animal metaphors presented by senex in the comedy Mercator see Enk (1979: pp. 7-21). 
sucked his father's money like an egg (fr. 3 K.-A.; Athenaeus 58a). This motif was exploited in Latin literature e.g. by Caecilius Statius in the comedy called Synephebi ("The young men").

\begin{abstract}
Caec. St. Synephebi frg. I R3:
In amore suave est summo summaque inopia

Parentem habere avarum inlepidum, in liberos

Difficilem, qui te nec amet nec studeat tui.
\end{abstract}

\begin{abstract}
Aut tu illum furto fallas aut per litteras
Avertas aliquod nomen aut per servolum

Percutias pavidum, postremo a parco patre

Quod sumas quanto dissipes libentius!
\end{abstract}

"It is sweet to love so much and suffer from poverty, when you have an unpleasant and avaricious father, harsh for the children who does

not love you nor cares for you.

You may deceive him with theft or twisting the name of your creditor or lying to the scared slave

At last, what you take from your avaricious father, you will spend with much greater pleasure."

The Atellan farce of the same title, Synephebi, was written by Pomponius, but it is not possible to prove that this farce originated from Caecilius Statius' palliata. Similarly, we cannot be certain that this farce exploited the motif of adulescens stealing money from his father - the one surviving fragment does not confirm this assumption. ${ }^{42}$ However, there are two fragments from other Atellan plays, presenting the character of a young son. He appears in a play written by Pomponius (Sarcularia - "A comedy about the hoe") and in the first fragment of the play Agricola" ("The farmer") by Novius.

\footnotetext{
Pomp. Sarcularia (v. 162): alter amat, potat, prodigit, patrem subpilat semper

"One of them loves, drinks, squanders money and always robs his father in secret"

Nov. Agricola frg. I (v. 1): edepol, paternam qui comest pecuniam

"On Pollux, he consumes completely all his father's money"
}

In both of these fragments adulescens is depicted as a son who wastes his father's money, especially spending it on banquets. In Sarcularia a young man is presented as a stock character from palliata with his significant features - he is in love (amat), he drinks frequently (potat) and steals money from his father unobtrusively (subpilat). The last verb, subpilare, has probably also been borrowed from palliata - it is a funny word, preserved only in comedies, where it denotes stealing secretly from the wife or from the father (cf. Pl. As. 815; 888; Men. 740; 803; Truc. 566a; Caec. St. Nauclerus frg. III R ${ }^{3}$ ). The second passage shows that the son has wasted all of his father's money (comest). The verb

42 Pomp. Synephebi: incolume illo; "him unharmed".

43 The second fragment may describe a character of senex amator, being a rival of his son (Nov. Agricola II): quid ita? quia enim repuerascis, fugitas personas, pater. "Why then? Because you make yourself younger, you try to avoid masks, father." 
comesse $^{44}$ also occurs in earlier comedies - as in palliata (Pl. Bac. 743; Trin. 406), as in togata (Titin. Fullonia vel Fullones frg I Guardí). ${ }^{45}$

There is one more fragment from the farce entitled Praefectus morum ${ }^{46}$ ("An official in charge of the customs") which might refer to the son's deception of the father. Deception could be the reason why adulescens wants to hide his face before his father.

Pomp. Praefectus morum frg. II (v. 147): pater adest. negato esse hic me; ego operibo caput.

"Father has come here. If only he could deny that I'm also here; I'll hide my face"

Although this interpretation is probable, it must remain a hypothesis, because of scarce evidence of this fragment and other testimonies.

The last passage ${ }^{47}$ related to the father and son figures I would like to quote here, comes from a play by Novius.

Nov. Pappus Praeteritus (vv. 74-75): dum istos invitabis suffragatores, pater,

prius in capulo quam in curuli sella suspendes natis.

"If you invite those supporters, father, you may rather put your ass in the coffin than in the office chair."

The text comprises an utterance made by a young man who laughs at his father. The joke is very expressive and blunt, because the son, giving his opinion on his father's application for the office of aedilis curulis, uses a vulgar word to depict his parent's ass and makes fun of his death. This kind of a low and rude banter, which contains terms of abuse denoting the character of a father, would be typical rather for Atellana and does not originate from palliata.

\section{Virgo - Filia}

Among the family stock figures from palliata we need to discuss also the mask of a virgo. She is often depicted in the comedy as a daughter of a noble citizen, she rarely even

44 Cf. Pl. Mer. 238-239: dicit capram (...) suae uxoris dotem ambedisse oppido.

45 Titin. Fullonia vel Fullones frg. I Guardí: ego me mandatam meo viro male arbitror/qui rem disperdit et meam dotem comest.

46 In Plautine Aulularia the avaricious Euclio forces Megadorus to admit that he acts as a guard of female

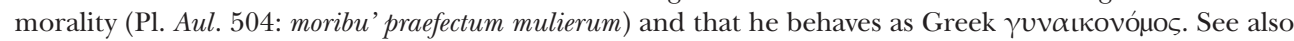
Fredershausen (1906: pp. 53-54).

47 Although there are five more fragments which mention the father figure, they do not show any apparent references to palliata, which is a subject of this article - that is why I resigned from presenting them in the main text. These are: Pomp. Praeco posterior frg. X, v. 141-143 (see note no. 33); Pomp. Vacca vel Marsuppium, vv. 170-172; Nov. Agricola frg. II, v. 2 (see note no. 39); Nov. Inc. fab. rel. frg. VII, vv. 108-109; Inc. nominis reliquiae frg. V, v. 5. The same conclusion concerns the son's mask who is mentioned as natus/ gnatus also without references to palliata in the fragments: Nov. Andromacha, vv. 4-5; Nov. Duo Dossenni, v. 19; Nov. Hetaera, v. 42. 
appears on stage, as it is inappropriate for such a virtuous young girl to take part in the hilarious situations of the comedy. Nonetheless, virgo is sometimes presented in palliata as seduced or raped by a young man during some kind of a festival. Later it turns out that she got pregnant and from this moment the plot of the play moves towards a happy ending between two young lovers. This motif, taken from the Greek new comedy (cf. "The Samian girl" by Menander) is exploited e.g. in the comedy Hecyra ("The mother-inlaw") created by Terence.

Ter. Hec. 831-832: (...) inde est cognitio facta

Philumenam compressam esse ab eo et filium inde hunc natum.
"That's how it came out that it was Philumena who

had been raped by him and it is his son who has now been born."

Atellan farce alludes to this theme of a pregnant and seduced girl in the comedy Virgo praegnans which means "The pregnant girl" or "The pregnant virgin" - the title could contain a contradictory juxtaposition ${ }^{48}$ and a joke.

Nov. Virgo praegnans frg. I (vv. 94-95): quanto ego

plus sapivi, quin' fullonem compressi Quinquatrubus!

"How smarter I was, that I mounted the fuller during the Minerva festival."

What is worth to notice is that in both passages from Terence and Pomponius the same verb comprimere is applied to denote the seduction. ${ }^{49}$ The preserved fragment of this play contains the statement of a seducer himself, who made love during the festival with a person whom he calls a fuller - a craftsman/worker washing and dyeing cloths. Hence we may assume that the traditional motif of a seduced girl got a farcical nature in this Atellana. Here a man, not a young girl, is being seduced and the relation between characters becomes homosexual. What is interesting is that the allusion to a craftsman and the festival dedicated to Minerva, i.e. a festival popular among the craftsmen let us believe that these motifs were borrowed from fabula togata, a kind of comedy focusing on Roman topics, especially on the life of craftsmen, workers and artisans. Consequently, the quoted fragment comprises traditional elements taken from two different types of comedy - the character of a girl seduced during a feast comes from palliata, but the role of a girl is played by a craftsman from togata and the festival is organized by the workers. As we can see - the popular farce employed, laughed at and mixed conventional components of different types of comedy, apart from their origin.

An analogical picture is given by a farce called Maccus virgo - "Maccus as a girl" or "Maccus a virgin". Even the title proves that the conventional motif has been transformed in this comedy - a stock character from Atellana, Maccus who was a stupid

48 Hurbánková (2010: p. 73).

49 W. Bannier, ThLL, vol. III, col. 2157, 70-84 and 2158, 1-7; Adams (1990: pp. 182-183). Cf. the verb comprimere in Pl. Aul. 28; 29; 30; 33; 689; Cist. 158; 162; 616; Epid. 540; Caec. St. Davos R'; Ter. Ph. 1018; Hec. 572; 828; Prop. 2, 26, 48; 2, 30, 35. There is also a title of Plautine play Bis compressa, but we do not know for sure if the participle refers to sexual issues. 
glutton, takes the role of a young girl. Again, the homosexual relation ${ }^{50}$ is being suggested in this play, not only by the title, but also by the preserved fragment. The passage depicts Dossennus, a stock character from the farce, a clever crafty crook, having an intercourse with some other man, maybe with Maccus, the protagonist mentioned in the title of the comedy. The description of Maccus as a girl suggests his passive role in this homosexual relation and the same allusion is given in the quoted passage. ${ }^{51}$

\section{Pomp. Maccus virgo (vv. 71-72): praeteriens vidi Dossennum in ludo reverecunditer non docentem condiscipulum, verum scalpentem natis.}

"Passing by, I saw Dossennus during a festival reverentially not teaching his co-pupil, but carving his ass."

The proverb reverecunditer gives some erotical irony ${ }^{52}$ to the passage, the opposition between the two homoioteleuta: docentem et scalpentem has also the same function. Scalpere is a synonym to pedicare - it describes a homosexual intercourse in which natis euphemistically denotes the "anus" ${ }^{53}$ of one of the men. Therefore, we must admit that the stock character of virgo is used here only as a foundation for obscene jokes and the erotic creation of Maccus.

We may conclude that the character of a daughter, a pregnant and seduced young girl, was changed significantly by the popular farce. ${ }^{54}$ Only those features of a girl and a daughter that referred to the area of erotica had been transposed from palliata to Atel$l a n a$, and then they were greatly exaggerated and twisted by this genre.

\section{Servi}

The last members included in the palliata family were the slaves. What is interesting is that they generally do not appear in the surviving texts of Atellan plays. Only one fragment alludes to servi who are being called "filthy comic slaves", but this description probably does not originate from palliata.

Pomp. Praeco posterior frg. VI (v. 136): si sciam quid velis, quasi servi comici conmictilis

"If I knew what you wanted, as do the filthy slaves from the comedy"

The only element linking this passage with the figure of the slave in palliata would be an assumption that a servus is the person who knows everything. Indeed, the slave in palliata

50 Cf. Piwonka (1949: p. 256).

51 Hurbánková says that the title refers to Maccus' innocence (2010: p. 73).

52 Danese (2010: p. 113).

53 Danese (2010: p. 114) after Marzullo (1973: pp. 11, 27).

54 There is one more fragment mentioning the figure of filia, but the passage does not allude to palliata - Nov. Surdus, v. 83. The fragment no. V from Pomponius' Auctoratus (v. 19: si praegnans non es, paribis nunquam) although contains a word praegnans, refers rather to a mask of a parasite. 
is often omniscient and omnipotent (he invents and develops the whole plot in the play).

Among the servi in the comedy we can find also feminine roles. A passage from the play entitled Macci gemini shows the character of anus, an old woman slave. She is often presented in palliata as a tuteress and a servant, working for the family. What indicates that this figure is mentioned here and not e.g. an old wife, is a remark about mola a millstone.

Pomp. Macci Gemini frg. II (v. 62): iam ego inibi adero: dum ego revortor age, anus, accinge ad molas "I will be just there: when I come back, be ready, old woman, for the millstone"

The person speaking here, probably the master, senex, threatens the woman that she would be castigated in a way that the slaves in palliata were punished, or were often threatened to be punished ${ }^{55}$ (the motif of a beaten slave is taken from Greek new comedy - cf. the term $\mu \alpha \sigma \tau \iota \gamma$ í $\alpha \varsigma)$. In Plautus' comedy Persa we find a dialog between two slaves who joke about one of them being punished in a mill (apud molas).

Pl. Persa 21-22:

SAG. negotium edepol - TO. ferreum fortasse? SAG. Plusculum annum

fui praeferratus apud molas tribunus vapularis.

"S. Oh well, my business - T. Ironware, perhaps? S. For more than a year I have been Minister Extrairondinary and Plentyblowtentiary at the mills."

These are all fragments from Atellana alluding to the character of a slave. The number of these passages is a little bit surprising, because servus was an important figure in palliata, especially in Plautus' plays. The slave acted as an architect of a plot and a spiritus movens of the comedy ${ }^{56}$ (Pl. Mil. 901: hic noster architectust; por. Ps. 401-405). It seems that Atellana has resigned of this character's role in a play, giving more attention to other family members.

To conclude, we need to notice with certainty that the stock characters from palliata were borrowed into Atellana with their specific features and that this literary device concerned all the family masks. Nonetheless, sometimes the popular farce transforms the attributes of these characters to exploit and sharpen the features which suit the farcical nature of Atellana. Therefore, it exaggerates especially the sexual connotations referring to the characters and uses more terms of abuse. In such a way Atellana increases the comicality of its characters. To achieve the goal of a farce, which is to create "vis comica within narrow limits" 57 of a play, Atellana also mixes the stock characters and their features known from different types of comedy, e.g. from palliata and togata, or transposes the features of palliata's characters to Atellana's stock characters. Concluding, we may

55 Cf. Pl. As. 29-42; Naev. inc. fab. (frg. VII R ${ }^{3}$ ): Tantum ibi molae crepitum faciebant, tintinnabant compedes.

56 Plautus developed the role of the slave in the comedy which he transferred from Greek plays (Fraenkel 2007: pp. 159-172). Cf. Alliaud (1988: pp. 15-26).

57 Stephenson (1960: p. 91). 
admit that Atellana presents the family life modelled on palliata, but it shows the stock characters in caricature and emphasizes their roles as objects of sexual interest. In this way Atellana achieves its nature full of burlesque, mockery, as well as the rustic, crude $^{58}$ and obscene elements.

\section{Bibliography}

Adams, J. N. (1990). The Latin Sexual Vocabulary. London: Johns Hopkins University Press.

Alliaud, M. (1988). La figura del servo in Menandro. Zetesis, 8(1), 15-26.

Barsby, J. (Ed.). (2001). Terence: Phormio, The Mother-in-law, The Brothers (Vol. 2). Cambridge: Harvard University Press.

Christenson, D. M. (Ed.). (2005). T. M. Plautus: Amphitruo. Cambridge: Cambridge University Press.

Couto, A. P. (2007). A rivalidade pai/filho no Mercator de Plauto. Ágora. Estudos Clássicos em Debate, 9, 41-73.

Culham, P. (1982). Lex Oppia. Latomus, 41, 786-793.

Danese, R. M. (2010). Stile e sesso nei frammenti dell' Atellana letteraria. In R. Raffaelli, \& A. Tontini (Eds.), L'atellana letteraria, Atti della Prima Giornata di Studi sull' Atellana (pp. 101-117). Urbino: Quattroventi.

Debouy, E. (2010). The Titles of the Atellanae: an Attempt at a Typology. In R. Raffaelli, \& A. Tontini (Eds.), L'atellana letteraria, Atti della Prima Giornata di Studi sull'Atellana (pp. 157-168). Urbino: Quattroventi.

Della Corte, F. (1978). La tipologia del personaggio della palliata. Opuscula, 6, 155-194.

Duckworth, G. E. (1952). The Nature of Roman Comedy: A Study in Popular Entertainment. Princeton: University of Oklahoma Press.

Enk, P. J. (Ed.). (1979). T. M. Plautus: Mercator (Vol. II). New York: Arno Press.

Forcellini, E. (Ed.). (1828). Totius Latinitatis Lexicon (Vol. II). Londini: Baldwin and Cradock [etc.]. Fraenkel, E. (2007). Plautine Elements in Plautus (Transl. T. Drevikovsky, \& F. Muecke). Oxford: Oxford University Press.

Frassinetti, P. (Ed.). (1967). Atellanae fabulae. Romae: In aedibus Athenaei.

Fredershausen, O. (1906). De iure Plautino et Terentiano. Göttingen: Goldschmidt \& Hubert.

Graziani, F. (1896). I personaggi dell'Atellana. Rivista di Filologia e d'Istruzione Classica, 24, 388-392.

Henderson, J. (1975). The Maculate Muse. Obscene Language in Attic Comedy. New Haven, CT: Yale University Press.

Hopfner, T. (1938). Das Sexualleben der Griechen und Römer. Prague: J. G. Calve.

Hurbánková, Š. (2008). Personae oscae e il riso popolare nelle atellane. Graeco-Latina Brunensia, 13, 67-79.

Hurbánková, Š. (2009). Personae oscae delle atellane. Rassegna storica dei comuni, 35, 7-15.

Hurbánková, Š. (2010). Characters and Comic Situations in Roman Comedy: The Atellan Farce and Mime. Graeco-Latina Brunensia, 15(2), 69-80. 
Hurbánková, Š. (2014). Repertoire of Characters in Roman Comedy: New Classification Approaches. Graeco-Latina Brunensia, 19(2), 3-15.

Kupiszewski, H. (1962). Dyskolos Menandra i jego znaczenie dla prawa greckiego i rzymskiego. Eos, 52(1), 47-56.

Kuryłowicz, M. (1994). Prawo i obyczaje w starożytnym Rzymie. Lublin: Lubelskie Wydawnictwa Prawnicze.

Lefèvre, E. (2010). Atellana e Palliata: gli influssi reciproci. In R. Raffaelli, \& A. Tontini (Eds.), L'atellana letteraria, Atti della Prima Giornata di Studi sull' Atellana (pp. 15-36). Urbino: Quattroventi.

Lelewska, B. M. (1998). Żona posażna w komediach Plauta. Meander, 53(1), 15-23.

Leo, F. (1895). Plautinische Forschungen. Zur Kritik und Geschichte der Komödie. Berlin: Weidmann. Lindsay, W. M. (Ed.). (1910). T. M. Plautus: Comoediae (Vol. I and II). Oxford: Clarendon Press.

MacCary, W. T., \& Willcock, M. M. (Eds.). (2004). T. M. Plautus: Casina. Cambridge: Cambridge University Press.

MacCary, W. T. (1971). Menander's Old Men. Transactions and Proceedings of the American Philological Association, 102, 303-325.

Manuwald, G. (2011). Roman Republican Theatre. Cambridge: Cambridge University Press.

Marzullo, A. (1973). Dalla satira al teatro popolare latino. Ricerche varie. Milano: Ceschina.

Maurice, L. (2003). Amici et sodales: An Examination of a Double Motif in Plautus. Mnemosyne, 56(2), 164-193.

McDonnell, M. (1983). Divorce Initiated by Women in Rome: The Evidence of Plautus. American Journal of Ancient History, 8, 54-80.

Nixon, P. (Ed.). (1916). Plautus: Amphitryon, The Comedy of Asses, The Pot of Gold, The Two Bacchises, The Captives (Vol. 1). London: William Heinemann.

Nixon, P. (Ed.). (1917). Plautus: Casina, The Casket Comedy, Curculio, Epidicus, The Two Menaechmuses (Vol. 2). London: William Heinemann.

Nixon, P. (Ed.). (1924). Plautus: The Merchant, The Braggart Warrior, The Haunted House, The Persian (Vol. 3). London: William Heinemann.

Perna, R. (1955). L'originalità di Plauto. Bari: Leonardo da Vinci Editore.

Pezone, F. E. (1969). Persone e parole di fabulae Atellanae. Rassegna storica dei comuni, 1, 206-210. Pieczonka, J. (2007). Ustawy okresu republikańskiego w komediach Plauta. Classica Wratislaviensia, 27, 113-126.

Piwonka, P. (1949). Lucilius und Kallimachos: zur Geschichte einer Gattung der hellenistisch-römischen Poesie. Frankfurt: Klostermann.

Preston, K. (1916). Studies in the Diction of the Sermo Amatorius in Roman Comedy. Diss. Chicago.

Ribbeck, O. (1898). Scaenicae Romanorum poesis fragmenta. Vol. II: Comicorum Romanorum praeter Plautum et Terentium reliquiae (3. ed.). Lipsiae: In aedibus B. G. Teubneri.

Rosenmeyer, P. A. (1995). Enacting the Law: Plautus' Use of the Divorce Formula on Stage. Phoenix, 49(3), 201-217.

Roy, J. (1999). Polis and oikos in Classical Athens. Greece and Rome, 46, 1-18.

Schuhmann, E. (1977). Der Typ der 'uxor dotata' in den Komödien des Plautus. Philologus, 121, 45-65.

Sitti, K. (1895). I personaggi dell'Atellana. Rivista di storia antica e scienze affini, 3, 27-30.

Skwara, E. (2001). Historia komedii rzymskiej. Warszawa: Prószyński i S-ka. 
Stephenson, R. C. (1960). Farce as Method. The Tulane Drama Review, 5(2), 85-93.

Tarwacka, A. (2002). Rozwód Carviliusa Rugi - czy naprawdę pierwszy? Czasopismo Prawno-Historyczne, 54(1), 301-308.

Tarwacka, A. (2004). 'Ei foras, mulier', czyli rozwód w komediach Plauta. Zeszyty Prawnicze UKSW, $4(1), 7-26$.

Tarwacka, A. (2005). W krzywym zwierciadle: Satyrycy okresu pryncypatu o repudium. In H. Kowalski, \& M. Kuryłowicz (Eds.), 'Contra leges et bonos mores'. Przestepstwa obyczajowe w starożytnej Grecji i Rzymie (pp. 355-362). Lublin: Wyd. Uniwersytetu M. Curie-Skłodowskiej.

Walker, S. L. (1980). The senex amator in Plautus. Diss. Chapel Hill.

Watson, A. (1967). The Law of Persons in the Later Roman Republic. Oxford: Clarendon Press.

Wright, J. (1974). Dancing in Chains: the Stylistic Unity of the Comoedia Palliata. Rome: American Academy.

Dr. Joanna Pieczonka / joannapieczonka@gmail.com

Institute of Classical, Mediterranean and Oriental Studies

University of Wrocław, Faculty of Philology

Komuny Paryskiej 21, 50-451 Wrocław, Poland 